

DIPARTIMENTO DI ECONOMIA

\title{
Financial Constraints and Firm Export Behavior
}

Flora Bellone

Patrick Musso

Lionel Nesta

Stefano Schiavo 
The Discussion Paper series provides a means for circulating preliminary research results by staff of or visitors to the Department. Its purpose is to stimulate discussion prior to the publication of papers.

Requests for copies of Discussion Papers and address changes should be sent to:

Dott. Luciano Andreozzi

E.mail luciano.andreozzi@economia.unitn.it

Dipartimento di Economia

Università degli Studi di Trento

Via Inama 5

38100 TRENTO ITALIA 


\title{
Financial Constraints and Firm Export Behavior
}

\author{
Flora Bellone* $^{*} \quad$ Patrick Musso $^{\dagger} \quad$ Lionel Nesta $^{\ddagger} \quad$ Stefano Schiavo $^{\S}$
}

October 2008

\begin{abstract}
The paper analyzes the link between financial constraints and firm export behavior. Our main finding is that firms enjoying better financial health are more likely to become exporters. The result contrasts with the previous empirical literature which found evidence that export participation improves firm financial health, but not that export starters display any ex-ante financial advantage. On the contrary, we find that financial constraints act as a barrier to export participation. Better access to external financial resources increases the probability to start exporting and also shortens the time before firms decide to serve foreign customers. This finding has important policy implications as it suggests that, in presence of financial markets imperfections, public intervention can be called for to help efficient but financially constrained firms to overcome the sunk entry costs into export markets and expand their activities abroad.
\end{abstract}

Keywords: Export; Firm heterogeneity; Financial constraints; Sunk costs

JEL Classification: F14; G32; L25; D92

\section{Introduction}

The paper analyzes the link between financial factors and firm export behavior exploiting a large dataset on French manufacturing firms. There are several reasons making this a relevant issue. With the rise of the 'global economy' export performance is increasingly perceived as a key aspect of economic performance, both for firms and for the entire macroeconomic outlook. In the meantime, academics have been paying increasing attention to firm level studies. Wider access to firm level data, greater computational

\footnotetext{
*University of Nice - Sophia Antipolis, GREDEG (CNRS). E-mail: Flora.Bellone@gredeg.cnrs.fr

${ }^{\dagger}$ University of Savoie, IREGE (IMUS) and CERAM Business School. E-mail: Patrick.Musso@univsavoie.fr

${ }^{\ddagger}$ Observatoire Français des Conjonctures Economiques, Département de Recherche sur l’Innovation et la Concurrence (OFCE-DRIC). E-mail: Lionel.Nesta@ofce.sciences-po.fr

${ }^{\S}$ Corresponding author: University of Trento, Department of Economics and OFCE-DRIC. E-mail: sschiavo@economia.unitn.it
} 
capabilities, as well as theoretical advances that depart from the representative agent framework have led economists to recognize that aggregate dynamics are the result of microeconomic behavior. Thus, a clear grasp of the latter becomes crucial to understand the former and to design appropriate policies.

In this paper we refer to export behavior in terms of both export participation and export intensity. A vast empirical literature documents a substantial heterogeneity across firms (ISGEP, 2008). Differences in firm export behavior has mostly been explained in terms of systematic differences between firms in productivity levels. We rely on the idea of heterogeneity of financial constraints to account for export behavior.

Our theoretical background is casted in terms of the recent 'new-new' trade theory (Melitz, 2003) which emphasizes both firm heterogeneity and the relevance of sunk entry costs into export markets. ${ }^{1}$ Once extended to allow for imperfect capital markets, these models show that financial variables can play a key role in determining firm export behavior (Chaney, 2005; Manova, 2006). Indeed, the existence of sunk entry costs into export markets brings about the question of the financing of such expenditures that, by their very nature, are not matched by contemporaneous revenues. In the presence of financial market imperfections, it may well be - and this is the main research question from which we start - that only those firms that can successfully overcome this financial problem become exporters. In fact, this would be consistent with the evidence of internationalized firms outperforming non exporters in several dimensions as shown in the large literature triggered by Bernard and Jensen (1995).

Rather than supporting this prior, the scant empirical evidence on the topic suggests rather that exporting improves firm access to financial markets either by reducing informational asymmetries or by reducing exposure to demand-side shocks risk through diversification (Ganesh-Kumar et al., 2001; Campa and Shaver, 2002; Greenaway et al., 2007). In what follows we present an evaluation of the self-selection and ex-post effects based on a large panel of French manufacturing firms. Our contribution is twofold. First, we propose a new way to measure the degree of financial constraint (based on the multivariate index proposed by Musso and Schiavo, 2008), which we believe is superior to existing methodologies. Second, we shed light on the role played by access to external financial resources in shaping firm export behavior. In so doing, we do not limit ourselves to export participation, but we also look at export intensity.

We can summarize our main findings as follows. First, firms starting to export display a significant ex-ante financial advantage compared to their non exporting counterparts.

\footnotetext{
${ }^{1}$ The assumption that entry into foreign markets involves large sunk costs is not a novelty in the trade literature: see for instance Baldwin (1988); Roberts and Tybout (1997). This assumption is supported by an expanding empirical literature (see, among others, Bernard and Wagner, 2001; Das et al., 2001; Tybout, 2001; Bellone et al., 2008b).
} 
This in consistent with the idea that limited access to external financial funds may prevent firms from selling their products abroad. Second, we do not find significant evidence of any beneficial effect after entry into export markets. Hence, firms that start serving foreign markets do not improve their financial health as a consequence of exporting. When we dig deeper on the relation between financial factors and the decision to start exporting, we find that better access to financial markets increases the probability of firm internationalization, and also shortens the time before that happens. Finally, among the subsample of export starters, there is a negative relationship between export intensity and financial health. Considering the former as a proxy for the number of destinations served, our results suggest that entering simultaneously into many different markets entails larger sunk costs and results in a deterioration of a firm financial status.

The rest of the paper is organized as follows. Next Section presents an overview of the literature on financial constraints and firm export behavior. Section 3 presents the data, discusses the shortcomings of usual strategies employed to measure financial constraints, and illustrates the methodology adopted here. In Section 4, we test the two hypotheses that less constrained firms self-select into exporting, and that selling abroad improves firm financial health. We then look more in details at the role played by financial variables in shaping the decision to export: these results are discussed in Section 5. Section 6 concludes and draws some policy implications.

\section{A glance at the existing literature}

In presence of imperfect capital markets, one can figure out at least two reasons why exporting firms should be less financially constrained than non exporting firms.

First, if firms have to incur large sunk entry costs to enter into export markets, then enterprises unable to secure enough funds may be unable to serve foreign markets. This implies that only less constrained firms will be able to start exporting: such an idea is formalized by Chaney (2005) which adds liquidity constraints to a model of international trade with heterogeneous firms (in the spirit of Melitz, 2003). In fact, the new-new trade theory postulates that a large part of trade barriers faced by firms take the form of fixed costs to be paid up-front. The empirical literature documents significant hysteresis effects associated with firm export participation and interprets this as signalling the relevance of sunk entry costs: see for instance Roberts and Tybout (1997) for Colombia, Bernard and Wagner (2001) for Germany, Campa (2004) for Spain, Bernard and Jensen (2004) for the US. Das et al. (2001) estimate a structural model to quantify sunk costs and conclude that entry costs into export are substantial. In the business literature, Moini (2007) reports results form a survey among US non exporters, where firms claim their primary obstacle to initiate an export program is the presence of high up-front costs. 
Second, the very fact of exporting could improve firm access to external financial funds. Again there are different candidate explanations for such an effect. Exporting firms should in principle enjoy more stable cash flows, as they benefit from international diversification of their sales. Hence, under the assumption that international business cycles are only imperfectly correlated, exporting reduces vulnerability to demand-side shocks. This is the argument put forward by Campa and Shaver (2002) and Bridges and Guariglia (2008). Alternatively, selling in international markets can be considered as a sign of efficiency and competitiveness by domestic investors. In a context of information asymmetries which lie at the heart of financial markets imperfections - exporting would thus represent a clear signal about sent by the firm to external investors. Since only the best firms export — as we know very well by the large body of empirical literature triggered by Bernard and Jensen (1995), and as demonstrated theoretically by Melitz (2003) - then exporting represents by itself a sign of efficiency and a costless way for creditors to assess the potential profitability of an investment. Ganesh-Kumar et al. (2001) find that this kind of mechanism is especially relevant in an emerging market such India, characterized by low institutional quality. Finally, exporting is likely to open up access to international financial markets as well, at least those pertaining to the destination countries. In anything, foreign exchanges revenues represent a better collateral to access external funds in foreign financial markets. Once again this channel probably applies more directly to emerging economies, as postulated by Tornell and Westermann $(2003) .^{2}$

Empirically, Campa and Shaver show that investment is less sensitive to cash flow for the group of always exporters compared to the group of never exporters. Since in presence of perfect capital markets investment and cash flow should not be correlated, investment cash flow sensitivity is often regarded as a measure of financial constraints (more on this in Section 3.1 below). Also, when they consider firms that move in and out from export markets, the two authors find these appear more constrained during the periods when they only deal with local customers. Hence, they conclude that exporting can help firms to reduce their financial constraints. One possible weakness of the paper lies in the fact that export intensity plays no role in the play. In fact, if the diversification and the signaling channels were actually at work, one would expect a positive correlation between the how much a firm export (relative to its total sales) and its ability to reduce financial constraints. Yet, Campa and Shaver (2002) fail to find such a relationship.

Two recent papers provide further evidence backing the idea that exporting exerts a positive effect on firm financial health. Working with a large panel of UK manufactur-

\footnotetext{
${ }^{2}$ The relevance of the institutional context is witnessed by a recent work by Espanol (2003) who find exporting firms in Argentina more financially constrained than their competitors only serving the domestic market. This can be explained by the appreciation of the local currency in the early 1990s, which resulted in a profit squeeze for exporters, and weakened their balance sheets.
} 
ing firms Greenaway et al. (2007) look for a causal nexus between the two variables, and conclude that causality runs from export to financial health. In other words, they find no evidence in favor of the hypothesis of less constrained firms self-selecting into export activities, but rather strong evidence favoring a beneficial effect of the latter on financial health. ${ }^{3}$ In particular, they find no significant difference in the average liquidity (or leverage) ratio of export starters and never exporting firms. On the contrary, when comparing continuous exporters and starters, they find the former to enjoy a better average financial health over the sample period. Hence, they conclude that exporting does improve firm financial status, since participating to export for longer periods makes enterprises more liquid and less leveraged.

Bridges and Guariglia (2008) focus on survival among UK firms. More specifically, they look at the interrelations between global engagement (of which export is just one possible manifestation), financial health and survival. They find that lower collateral and higher leverage do result in higher failure probabilities, but only for purely domestic firms. They interpret this as evidence that international activities shields firms from financial constraints or, to put it in the terminology used so far, that internationalization is beneficial from a financial point of view.

Despite this body of literature, we claim that the issue is not fully settled yet. We base this statement on different considerations. First, the way financial constraints are identified and measured remains largely debated. As discussed below, the usefulness of investment cash flow sensitivity as a measure of financial constraints is increasingly challenged and recent theoretical works cast doubts also on other widespread proxies. Second, the role played by export intensity has been largely disregarded so far and remains to be determined. Last, the econometric specifications used in the literature appears not always consistent with the stated goal of testing the relevance of self-selection into export markets and of the existence of a beneficial effect of internationalization on firm financial health.

\section{Data and methodology}

We use data from two main sources. Both of them collects information on French firms, though their coverage is somehow different. The first (Enquête Annuelle d'Entreprises $E A E)$ is an annual survey that gathers balance sheets information for all manufacturing firms with at least 20 employees. ${ }^{4}$ The second source of information is the DIANE database

\footnotetext{
${ }^{3}$ We will discuss the issues related to the measurement of financial constrained in Section 3.1 below. For the moment, it suffices to say that Greenaway et al. (2007) use the liquidity ratio and the leverage ratio to proxy for financial constraints.

${ }^{4}$ The survey is conducted by the French Ministry of Industry. The surveyed unit is the legal (not the productive) unit, which means that we are dealing with firm-level data. To investigate the role of financial constraints on growth and survival, firm, rather than plant level data seem indeed appropriate.
} 
published by Bureau van Dijk, which collects data on over 1 million firms. It provides us with many financial variables absent from the $E A E$ survey. Merging the two datasets yields around 170,000 firm/year observations, stemming from an unbalanced panel of over 25,000 manufacturing enterprises followed over the period $1993-2005$.

\subsection{Measuring financial constraints}

The way financial constraints are measured is a very sensitive issue in the literature investigating the link between financial variables and firm behavior. Theory offers only limited guidance in this domain, so that a clear-cut consensus has still to emerge. Under perfect capital markets, internal and external sources of financial funds should be perfectly substitutable (Modigliani and Miller, 1958), so that the availability of internal funds should not affect investment decisions. Yet, when a standard investment equation is augmented with cash flow availability, the fit of the equation is improved. The most common proxy for financial constraints is thus the sensitivity of investment to cash flow. This methodology builds on Fazzari et al. (1988) who first define firms as financially constrained or unconstrained based on their dividend payout ratio, then show that likely constrained firms (low divided payout) display higher investment-cash flow sensitivity. A number of subsequent studies find supporting evidence using different variables to identify constrained firms (see for instance Bond and Meghir, 1994; Gilchrist and Himmelberg, 1995; Chirinko and Schaller, 1995).

On the contrary, Devereux and Schiantarelli (1990) find that larger firms (less likely to be constrained) exhibit a higher cash flow coefficient in the regression equation, even after controlling for sector heterogeneity. But it is only with the work by Kaplan and Zingales (1997) that the usefulness of investment-cash flow sensitivity as a measure of financial constraint has been definitely questioned. Since then, other authors have reported evidence of a negative relation between investment-cash flow sensitivity and financial constraints (for instance Kadapakkam et al., 1998; Cleary, 2006).

Alternative strategies consist of simply classifying firms according to various proxies of informational asymmetries (as these represent the main source of financial markets imperfections). Hence, variables such as size, age, dividend policy, membership in a group or conglomerate, existence of bond rating, and concentration of ownership (see for instance Devereux and Schiantarelli, 1990; Hoshi et al., 1991; Bond and Meghir, 1994; Gilchrist and Himmelberg, 1995; Chirinko and Schaller, 1995; Cleary, 2006) are used to capture ways to cope with imperfect information, which hinders access to capital markets. Other papers (e.g. Becchetti and Trovato, 2002) use survey data where firms give a self-assessment of their difficulty to obtain external financial funds.

The major weakness of these strategies — as already noted by Hubbard (1998) - is that most of the criteria tend to be time invariant whereas one can imagine that firms 
switch between being constrained or unconstrained depending on overall credit conditions, investment opportunities and idiosyncratic shocks. As a further potential problem, we add that all the abovementioned works rely on a unidimensional definition of financial constraint, i.e. they assume that a single variable can effectively identify the existence of a constraint, which is viewed as a binary phenomenon either in place or not. Notable exceptions are the works by Cleary (1999), Lamont et al. (2001) and Whited and Wu (2006). The first paper derives a financial score by estimating the probability of a firm reducing its dividend payments (viewed as a sign of financial constraints) conditional on a set of variables that are observable also in the case of unlisted firms. Lamont et al. (2001) build a multivariate index by collapsing into a single measure five variables weighted using regression coefficients taken from Kaplan and Zingales (1997). The main problem here rests with the need to extrapolate results derived from a small sample of US firms and apply them to a larger and different population. ${ }^{5}$ Based on a structural model, Whited and $\mathrm{Wu}$ (2006) use the shadow price of capital to proxy for financial constraints.

In the paper, we rely on four different measures of financial constraints. The first two are the liquidity ratio and the leverage ratio as employed by Greenaway et al. (2007). ${ }^{6} \mathrm{We}$ find two main shortcomings in these measures. First they only capture one dimension of access to financial markets: a firm may be liquid but nonetheless present a bad financial situation; on the other hand strong fundamentals may compensate for a temporary shortage of liquid assets. Second, both ratios may suffer from some endogeneity. In other words, there are no clear-cut theoretical priors on the relation between either liquidity or leverage and financial constraints. While generally regarded a sign of financial health, firms may be forced to be liquid by the fact that they are unable to access external resources. In fact, a recent theoretical contribution by Almeida et al. (2004) shows that financially constrained firms tend to hoard cash, so that liquidity would be associated with financial constraints, not lack thereof. In a similar vein, a high leverage, while signalling potential dangers, suggests also that the firm has enjoyed, at least in the recent past, wide access to external financial funds. Hence, one could argue that highly leveraged firms are not financially constrained. ${ }^{7}$

To account for these potential problems, we build two other measures of financial health according to the methodology first proposed by Musso and Schiavo (2008). They

\footnotetext{
${ }^{5}$ Furthermore, one of the variables needed to compute the index is Tobin's Q, whose use as a proxy for investment opportunities has often been criticized.

${ }^{6}$ The liquidity ratio is defined as a firm's current assets minus its short-term debt over total assets; the leverage ratio as a firm's short-term debt over current assets.

${ }^{7} \mathrm{~A}$ further problem is that leverage and liquidity appear as the financial variables best discriminating between exporting and non exporting firms in the sample analyzed by Greenaway et al. (2007). Therefore, one runs the risk of ending-up with some sort of a built-in relation between these two financial variables and export status (see Greenaway et al., 2005, for details on the choice of the financial variables).
} 
exploit information coming from seven variables: size (total assets), profitability (return on total assets), liquidity (current asset over current liabilities), cash flow generating ability, ${ }^{8}$ solvency (own funds over total liabilities), trade credit over total assets, and repaying ability (financial debt over cash flow) ${ }^{9}$

For each variable, we scale each firm/year observation for the corresponding 2-digit NACE sector average and then assign to it a number corresponding to the quintiles of the distribution in which it falls. ${ }^{10}$ The resulting information for each of the seven variables (a number ranging from 1 to 5 ) is then collapsed into a single index in two alternative ways: (i) a simple sum of the seven numbers (Score A); (ii) a count of the number of variables for which the firm/year lies in the first or second quintiles (Score B). ${ }^{11}$ In both cases the index is then rescaled to lie on a common 1-10 range.

Table 1: Correlations between Financial Constraints indexes

\begin{tabular}{lcccc}
\hline \multicolumn{4}{c}{ Pearson's r and Spearman } & Rho Correlation Coefficients \\
& Liquidity ratio & Leverage ratio & Score A & Score B \\
\hline \hline Liquidity ratio & - & -0.98 & 0.49 & 0.44 \\
Leverage ratio & -0.92 & - & -0.53 & -0.47 \\
Score A & 0.46 & -0.44 & - & 0.90 \\
Score B & 0.41 & -0.40 & 0.91 & - \\
\hline Numbers in italics denote Spearman rho correlation coefficients
\end{tabular}

The correlations between the four measures of financial constraints are presented in Table 1. Both the Pearson's and the Spearman correlation coefficients are reported, respectively below and above the main diagonal of the correlation matrix. Leverage and liquidity are strongly negatively correlated: more liquid firms are also less leveraged, meaning that these two measures of financial health go hand in hand. Something similar happens for the two multivariate scores: irrespective of the way information is combined firms are ranked in a very similar order in terms of access to external financial resources. This results in a Spearman rho correlation of 0.90, while Pearson's correlation coefficient reaches 0.91. Hence, Table 1 suggests that the two ratios, and the two scores provide very similar information. On the other hand, measuring financial constraints by means of a ratio or of

\footnotetext{
${ }^{8}$ This is the maximum amount of resources that a firm can devote to self-financing, and corresponds to the French capacité d'autofinancement.

${ }^{9}$ They are selected on the basis of their performance in existing studies, and their perceived importance in determining ease of access to external financial funds.

${ }^{10}$ Sectoral averages are taken to account for industry-specific differences in financial variables. Furthermore, to account for the presence of outliers we trim observations lying in the top and bottom $0.5 \%$ of the distribution for each the seven variables.

${ }^{11}$ We have tried also other ways to combine the information, with identical results. Additional details are available upon request.
} 
a multivariate index provides us with a different picture of the phenomenon at stake. In what follows we will concentrate on the liquidity ratio and on Score A only: both measures are increasing in financial health (contrary to leverage), which simplifies the discussion. Results are qualitatively unchanged if one uses the leverage ratio and Score B. ${ }^{12}$

\section{$3.2 \quad$ Firm productivity}

In the following empirical analysis we will often use measures of total factor productivity (TFP) to control for the existing heterogeneity among firms. TFP is computed using the so-called multilateral productivity index first introduced by Caves et al. (1982) and extended by Good et al. (1997). This methodology consists of computing the TFP index for firm $i$ at time $t$ as follows:

$$
\begin{aligned}
\ln T F P_{i t} & =\ln Y_{i t}-\overline{\ln Y_{t}}+\sum_{\tau=2}^{t}\left(\overline{\ln Y_{\tau}}-\overline{\ln Y_{\tau-1}}\right) \\
- & {\left[\begin{array}{l}
\sum_{n=1}^{N} \frac{1}{2}\left(S_{n i t}+\overline{S_{n t}}\right)\left(\overline{\ln X_{n i t}}-\overline{\ln X_{n t}}\right) \\
+\sum_{\tau=2}^{t} \sum_{n=1}^{N} \frac{1}{2}\left(\overline{S_{n \tau}}+\overline{S_{n \tau-1}}\right)\left(\overline{\ln X_{n \tau}}-\overline{\ln X_{n \tau-1}}\right)
\end{array}\right] }
\end{aligned}
$$

where $Y_{i t}$ denotes the real gross output of firm $i$ at time $t$ using the set of $N$ inputs $X_{n i t}$, where input $X$ is alternatively capital stocks $(K)$, labor in terms of hours worked $(L)$ and intermediate inputs $(M) . S_{n i t}$ is the cost share of input $X_{n i t}$ in the total cost. ${ }^{13}$ Subscripts $\tau$ and $n$ are indices for time and inputs, respectively, and upper bar denote sample means. This index makes the comparison between any two firm-year observations possible because each firm's inputs and outputs are calculated as deviations from a reference firm. The reference firm is a hypothetical firm that varies across industries ${ }^{14}$ with outputs and inputs computed as the geometric means of outputs and inputs over all observations and input cost-based shares computed as an arithmetic mean of cost shares over all observations. This non parametric measure of relative productivity has been popularized in the exportproductivity literature by the contributions of Aw et al. (2000), and Delgado et al. (2002).

\section{Export and finance: self-selection or ex-post benefit?}

We start our econometric analysis by explicitly testing the two hypotheses mentioned above, namely that less constrained firms self-select into export, and the possibility that exporting improves financial health. We then move to study the causal link running

\footnotetext{
${ }^{12}$ This second set of results is not reported but remains available upon request.

${ }^{13}$ See Bellone et al. (2008a) for more details on the method and a full description of the variables.

${ }^{14}$ Firms are allocated to one of the following 14 two-digit industries: Clothing and footwear; Printing and Publishing; Pharmaceuticals; House equipment and furnishings; Automobile; Transportation Machinery; Machinery and Mechanical equipment; Electrical and electronic equipment; Mineral industry; Textile; Wood and paper; Chemicals; Metallurgy, Iron and Steel; Electric and Electronic components.
} 
from financial variables to the decision of first exporting and, finally, we look at whether financial constraints play any role in determining export intensity.

\subsection{Descriptive statistics}

Table 2 presents descriptive statistics for the whole sample and also for different types of firms. We classify firms according to their export status separating those which export throughout the sample period (Continuous Exporters), those not exporting initially but entering foreign markets between 1993 and 2005 (Export Starters), and those always serving the domestic market only (Never Exporters).

Consistently with the large empirical literature on export and performance (started by Bernard and Jensen, 1995, and by now counting an endless number of replications) we find that exporters tend to be larger and more productive, as well as to pay higher wages. Similarly, exporting firms appear more liquid and display easier access to external financial funds as measured by Score A. Export starters lie somewhat in the middle of the two groups. The last column of the Table reports a F-test for equality of means across the three groups. The F-statistics are always larger than the $1 \%$ critical values, thus rejecting the null hypothesis of equal means across the different types of firms.

Table 2: Descriptive statistics

\begin{tabular}{lrrrrr} 
& All & Continuous & Export & Never & \\
& Firms & Exporters & Starters & Exporters & \multicolumn{1}{c}{ F-stat } \\
\hline \hline Employees & 88.083 & 115.839 & 59.672 & 56.799 & $1,477.65^{* * *}$ \\
TFP & 0.997 & 1.003 & 0.990 & 0.992 & $85.57^{* * *}$ \\
Wage per employee & 0.103 & 0.107 & 0.099 & 0.091 & $515.14^{* * *}$ \\
Score A & 5.620 & 5.825 & 5.448 & 5.261 & $1,133.34^{* * *}$ \\
Liquidity ratio & 0.293 & 0.320 & 0.273 & 0.240 & $727.78^{* * *}$ \\
\hline Observations & 167,597 & 85,720 & 63,402 & 18,475 & \\
\hline
\end{tabular}

On average, continuous exporters are double the size of non exporting firms in terms of employees, they pay salaries that are $17 \%$ higher and are $33 \%$ more liquid. The difference between starters and never exporters are much lower and, in terms of productivity the equality of means cannot be rejected.

\subsection{The ex-ante financial advantage of future exporters}

We start by comparing ex-ante financial health for exporters and non exporters. This tells us whether future exporters were less financially constrained than their non exporting counterparts even before entering foreign markets. The comparison is performed with firms belonging to the same industry and sharing similar characteristics in terms of size 
and efficiency. The econometric specification is adapted from the literature on export and performance (Bernard and Wagner, 1997; Bernard and Jensen, 1999), where this kind of empirical exercises are routinely performed. We focus our attention only on firms that do not exports in $t-1$ (or from $t-3$ to $t-1$ ), but may export in $t$. Hence $t$ is the year of entry into foreign markets (in the case of export starters), while we set it equal to the median year for never exporters. ${ }^{15}$ The comparison is performed one and three years before entry into export markets. Specifically, we estimate:

$$
F I N_{i, t-s}=\alpha+\beta E X P_{i t}+\gamma \mathbf{Z}_{i, t-s}+\varepsilon_{i t}
$$

where FIN is either Score A or the liquidity ratio, EXP is the dummy for export status, and $\mathbf{Z}$ a vector of controls that comprises Size (captured by the log of Employment, measured in terms of total hours worked), productivity (TFP), and a set of industry-year dummies.

It must be emphasized that Equation (2) does not test for a causal relationship. Rather, it allows us to evaluate the strength of the pre-entry premium -i.e. to see to what extent firms that export in time $t$ were already less financially constrained 1 and 3 years before entering foreign markets - by means of a simple t-test on the significance of the $\beta$ coefficient. Results are presented in Table 3.

Table 3: Self-selection into exporting by less constrained firms

\begin{tabular}{|c|c|c|c|c|}
\hline & \multicolumn{2}{|c|}{ Score A } & \multicolumn{2}{|c|}{ Liquidity ratio } \\
\hline & $\mathrm{t}-1, \mathrm{t}$ & $\mathrm{t}-3, \mathrm{t}$ & $\mathrm{t}-1, \mathrm{t}$ & $\mathrm{t}-3, \mathrm{t}$ \\
\hline & $(1)$ & $(2)$ & $(3)$ & $(4)$ \\
\hline \multirow[t]{2}{*}{ Export } & $0.161^{* * *}$ & $0.206^{* *}$ & $0.017^{*}$ & 0.003 \\
\hline & {$[0.052]$} & {$[0.095]$} & {$[0.010]$} & {$[0.016]$} \\
\hline \multirow[t]{2}{*}{$\log \mathrm{Empl}_{\cdot t-s}$} & $0.190 * * *$ & 0.073 & 0.006 & $-0.028^{* *}$ \\
\hline & {$[0.041]$} & {$[0.068]$} & {$[0.008]$} & {$[0.012]$} \\
\hline \multirow[t]{2}{*}{$\log \mathrm{TFP}_{t-s}$} & $2.809^{* * *}$ & $2.893^{* * *}$ & $0.356^{* * *}$ & $0.424^{* * *}$ \\
\hline & {$[0.141]$} & {$[0.249]$} & {$[0.026]$} & {$[0.043]$} \\
\hline Observations & 5772 & 2171 & 5772 & 2171 \\
\hline R-squared & 0.113 & 0.159 & 0.075 & 0.131 \\
\hline
\end{tabular}

When access to financial resources is measured by means of Score A, the coefficient of the export dummy is positive and significantly different from zero both in $t-1$ and in $t-3$. The better financial health of future exporters is less pronounced in terms of liquidity: they appear more liquid one year before entry, but not 3 years before.

\footnotetext{
${ }^{15}$ This means that we only focus on export starters (which have not been exporting before) and never exporters (which represent the control group).
} 
Overall, Table 3 provides convincing evidence that firms deciding to enter into foreign markets do enjoy better financial health ex ante. As discussed above, we claim that liquidity captures just one aspect of firm ability to access external financial resources, and we tend to give more credit to the multivariate index Score A. Let us note that equation (2) is estimated taking into account both successful exporters (i.e. those firms that keep exporting ever since their entry into foreign markets) and firms that stop exporting after a few years. This reduces potential sample selection biases and reinforces our results since it works against the hypothesis of self-selection.

\subsection{Detecting ex-post effects}

The results from the previous section suggest that less constrained firms tend to become exporters. This does not rule out the possibility that internationalization further boosts firm financial health. Here we look at the extent to which this happens while disregarding the specific reason behind the phenomenon: this is to say that we do not ask whether it is a diversification rather than a signaling effect that matter.

Once again we stick to an empirical specification taken from Bernard and Jensen (1999). The idea is very simple and consists in running a regression of the change in financial variables on initial export status and initial firm characteristics. From the previous section we know that exporters enjoy better access to external funds: if export participation is beneficial, then we should observe a differential in the way financial variables move after exporting firms have started to serve foreign markets. We focus on a subsample made of newly internationalized firms (export starters) and purely domestic enterprises, and we estimate the following equation:

$$
\Delta \% F I N_{i, t+s / t+q}=\alpha+\beta E X P_{i, t}+\gamma Z_{i, t}+\varepsilon_{i, t}
$$

where $\Delta \% F I N_{i, t+s / t+q}$ identifies the growth rate of the financial variable between time $t+s$ and $t+q$, whit $t$ being the first year of export. The coefficient $\beta$ represents the increase in the growth rate of the financial constrain measure of exporters relative to non exporters. If export is truly beneficial then we expect $\beta$ to be significantly different from zero.

As highlighted by estimated coefficients in Table 4 we do not find any evidence to support the idea that exporting improves firm access to external financial funds. We look at the growth of financial variables over a very short time span, namely between the first year of entry and the following year, and also over 3- and 5-year periods. In none of the cases is the export dummy significant. Arguably, this does not necessarily means that exporting does not affect financial health, but simply that beneficial effects do not appear within a 5-year horizon. Data limitations prevent us from looking at longer horizons, since we would end up with too few observations. 
Table 4: Measuring ex-post effects

\begin{tabular}{|c|c|c|c|c|c|c|}
\hline & \multicolumn{3}{|c|}{ Score A } & \multicolumn{3}{|c|}{ Liquidity ratio } \\
\hline & $t$ & $t+1$ & $t+1$ & $t$ & $t+1$ & $t+1$ \\
\hline & $t+1$ & $t+3$ & $t+5$ & $t+1$ & $t+3$ & $t+5$ \\
\hline & (1) & $(2)$ & $(3)$ & $(4)$ & $(5)$ & $(6)$ \\
\hline \multirow[t]{2}{*}{ Export } & 0 & 0.023 & 0.038 & 0.038 & -0.015 & -0.049 \\
\hline & {$[0.013]$} & {$[0.022]$} & {$[0.034]$} & {$[0.033]$} & {$[0.059]$} & {$[0.089]$} \\
\hline \multirow[t]{2}{*}{$\log \mathrm{Empl}_{t=0}$} & -0.014 & -0.001 & 0.022 & -0.039 & 0.001 & 0.001 \\
\hline & {$[0.009]$} & {$[0.013]$} & {$[0.018]$} & {$[0.026]$} & {$[0.039]$} & {$[0.052]$} \\
\hline \multirow[t]{2}{*}{$\log \mathrm{TFP}_{t=0}$} & $-0.181^{* * *}$ & 0.073 & -0.074 & 0.047 & -0.115 & -0.301 \\
\hline & {$[0.034]$} & {$[0.058]$} & {$[0.082]$} & {$[0.092]$} & {$[0.161]$} & {$[0.223]$} \\
\hline Observations & 4,391 & 1,836 & 1,164 & 3,321 & 1,462 & 913 \\
\hline R-squared & 0.052 & 0.085 & 0.112 & 0.042 & 0.089 & 0.141 \\
\hline
\end{tabular}

Equation (3) is estimated on the sample comprising export starters and never exporting firms only, but this time we have only retained successful entrants, i.e. only those firms that do not exit from foreign markets. Results are qualitatively unchanged if they are included: their exclusion should make easier to find an ex post benefit since the sample is biased in favor of the most successful firms.

In Section 2 above we have discussed two possible reasons why exporting may exert a positive effect on firm financial health, namely a diversification effect and a signaling effect. In both cases one could argue that the mere fact of selling part of the production above is not sufficient to trigger those beneficial effect, but rather there is a sort of threshold effect below which export does not count. In other words, it seems natural to look at whether export intensity plays a role in the game or not. As already mentioned, Campa and Shaver (2002) fail to find a relation between the share of sales to foreign customers and financial constraints, while Greenaway et al. (2007) disregard the issue.

To complement our analysis we augment equation (3) with the log of export intensity, defined as export over sales. Results, presented in Table 5 are less clear-cut that before, but point in the same direction. As one can see from Column (1) of the Table, in the first year after entry into export markets, higher export intensity is actually associated with an improvement of financial health as measured by Score A. Yet, this phenomenon appears short-lived: in fact it disappears when we move to longer time horizons. Furthermore, higher export intensity is not associated with more liquidity, not even in the first year after exporting. Thus, overall we do not find any compelling evidence that export participation improves firm financial health in the short and medium term. The result is confirmed when we re-estimate equation (3) on a subsample comprising only non exporting firms and those 
export starters characterized by an export intensity larger than the sector median. Results (not reported) mimic those already presented in Table 4 and therefore do not provide any support to the existence of a beneficial effect of exporting on financial health.

Table 5: Measuring ex-post effects controlling for export intensity

\begin{tabular}{|c|c|c|c|c|c|c|}
\hline & \multicolumn{3}{|c|}{ Score A } & \multicolumn{3}{|c|}{ Liquidity ratio } \\
\hline & $t$ & $t+1$ & $t+1$ & $t$ & $t+1$ & $t+1$ \\
\hline & $t+1$ & $t+3$ & $t+5$ & $t+1$ & $t+3$ & $t+5$ \\
\hline & $(1)$ & $(2)$ & $(3)$ & $(4)$ & $(5)$ & $(6)$ \\
\hline \multirow[t]{2}{*}{ Export } & -0.013 & 0.023 & 0.048 & 0.052 & -0.004 & -0.008 \\
\hline & {$[0.014]$} & {$[0.023]$} & {$[0.035]$} & {$[0.037]$} & {$[0.063]$} & {$[0.093]$} \\
\hline \multirow[t]{2}{*}{$\log \mathrm{Empl}_{t=0}$} & -0.014 & -0.001 & 0.021 & -0.039 & 0.001 & -0.004 \\
\hline & {$[0.009]$} & {$[0.013]$} & {$[0.018]$} & {$[0.026]$} & {$[0.039]$} & {$[0.052]$} \\
\hline \multirow[t]{2}{*}{$\log \operatorname{TFP}_{t=0}$} & $-0.182^{* * *}$ & 0.073 & -0.070 & 0.049 & -0.111 & -0.288 \\
\hline & {$[0.034]$} & {$[0.058]$} & {$[0.082]$} & [0.092] & {$[0.162]$} & {$[0.223]$} \\
\hline \multirow[t]{2}{*}{$\log (\operatorname{Exp} \operatorname{Int})_{t=0}$} & $0.136^{* *}$ & -0.002 & -0.114 & -0.153 & -0.111 & -0.533 \\
\hline & [0.069] & {$[0.087]$} & {$[0.125]$} & {$[0.177]$} & {$[0.238]$} & {$[0.346]$} \\
\hline Observations & 4,391 & 1,836 & 1,164 & 3,321 & 1,462 & 913 \\
\hline R-squared & 0.053 & 0.085 & 0.113 & 0.042 & 0.089 & 0.143 \\
\hline
\end{tabular}

\section{$5 \quad$ Modelling the decision to start exporting}

Firm export behavior must ultimately be conceived as a series of decisions regarding both participation to export markets and the firm's commitment to international trade. These decisions can be modelled as the outcome of a variety of factors. Heterogeneity of firm productivity levels is the utmost explanation for the observed differences in export behavior across firms. Because firms are heterogeneous in their productive efficiency, they all have an idiosyncratic ability to cope with the sunk costs associated with entry into export markets. Yet this may not exhaust the explanation The firm's ability to access external financial resources may well constitute another important part of the story. In this section, we investigate the factors driving firm decisions to enter into export market in the first place, to then analyze the determinants of export intensity. Taking stocks of our previous findings, we expect financial constraints to be an important driver of export behavior by firms, controlling for other important factors such as productivity, human capital and firm size, and mobilize two series of specifications that account for time duration and selection biases, respectively. 


\subsection{Accounting for time duration to export markets}

To model firm entry decision into foreign markets in terms of time duration is tantamount to equating firm growth with entry into export markets. French data reveal that $70 \%$ of firms with more than 20 employees will ultimately penetrate foreign markets. This proportion increases to $95 \%$ for large firms (i.e. with more than 500 employees). This suggests that entry into export markets by firms is a necessary - yet significant - step for growth. Hence the relevant issue is not so much whether firms enter into export market. Rather, the issue is one of time duration and the time length is takes for a firm to eventually reach foreign destinations. This Section tackles this issue explicitly using discrete time duration models.

We estimate a duration model for grouped data following the approach first introduced by Prentice and Gloeckler (1978). Suppose there are firms $i=1, \ldots, N$, that enter the industry at time $t=0$. The hazard rate function for firm $i$ at time $t$ and $t=1, \ldots, T$ to start exporting is assumed to take the proportional hazard form: $\theta_{i t}=\theta_{0}(t) \cdot X_{i t}^{\prime} \beta$, where $\theta_{0}(t)$ is the baseline hazard function and $X_{i t}$ is a series of time-varying covariates. More precisely, let $X=\{E M P ; W P E ; T F P ; S u b s ; F I N\}$, where EMP stands for employment weighted by the numbers of hours worked, $W P E$ is the wage bill per employee in order to control for systematic differences between firms in terms of human capital, TFP is total factor productivity, Subs is set to unity if firms has one or more subsidiaries and FIN is a measure of financial constraints. The discrete time formulation of the hazard rate of first export for firm $i$ in time interval $t$ is given by a complementary log logistic function such as:

$$
h_{t}\left(X_{i t}\right)=1-\exp \left\{-\exp \left(X_{i t}^{\prime} \beta+\theta(t)\right)\right\}
$$

where $\theta(t)$ is the baseline hazard function relating the hazard rate $h_{t}\left(X_{i t}\right)$ at the $t^{t h}$ interval with the spell duration (Jenkins, 1995). Finally, we model the baseline hazard function by using the log-transformed of $\theta(t)$, an integer counting the number of years of presence in the market. This choice is discrete-time counterpart of a continuous-time specification with a Weibull hazard function. ${ }^{16}$

This model can be extended to account for unobserved heterogeneity —or 'frailty', to account for systematic differences between firms. ${ }^{17}$ In a way, the inclusion of unobserved heterogeneity is a generalization of a pooled specification ignoring it. First, it allows

\footnotetext{
${ }^{16}$ We have experimented for alternative specifications, namely the semi-parametric, polynomial specification using time together with its squared $\theta(t)^{2}$ and cubic values $\theta(t)^{3}$, and a fully non-parametric approach using duration-interval-specific dummy variables. Because this choice does not affect the conclusions, we do not report the results from these specifications, but they are available on request.

${ }^{17}$ The term 'frailty' comes from medical sciences where it represents the unobserved propensity to experience an adverse health event.
} 
the omitted variable bias and controls for measurement errors in observed survival times and regressors (Jenkins, 1995). Suppose that unobserved heterogeneity is described by a random variable $\varepsilon_{i}$ independent of $X_{i t}$. The proportional hazard form with unobserved heterogeneity can now be written as:

$$
h_{t}\left(X_{i t}\right)=1-\exp \left\{-\exp \left(X_{i t}^{\prime} \beta+\theta(t)\right)+\varepsilon_{i}\right\}
$$

where $\varepsilon_{i}$ is an unobserved individual-specific error term with zero mean, uncorrelated with the $X$ 's. Model (5) can be estimated using standard random effects panel data methods for a binary dependent variable, under the assumption that some distribution is provided for the unobserved term. In our case, we will assume that the $\varepsilon_{i}$ are distributed Normal and Gamma (See Jenkins, 1995, for more details). Note that our comments will focus on the Gamma distribution exclusively, and other estimates are provided as robustness checks. ${ }^{18}$ Lastly, we perform a likelihood ratio test between the unrestricted model (with unobserved heterogeneity) and the restricted model (without unobserved heterogeneity) to test for the relevance of unobserved frailty. The reported estimates are chosen from the $\log$ likelihood ratio test (LR test).

The results are displayed in Table 6, where Score A and the liquidity ratio have been used as proxies for financial constraints. The first two columns provide estimate for discrete the duration model for pooled data. Columns (3) to (6) display the estimated parameter controlling for unobserved heterogeneity, which is sequentially assumed to be normal distributed (columns 3 and 4) and Gamma distributed (columns 5 and 6). Generally speaking, all specifications exhibit strong consistency in the direction and significance of the parameter estimates. Observing the significance of the LR test, we comment on the specification controlling for unobserved heterogeneity exclusively.

Particularly satisfactory is the consistency and significance of the two measures of financial constraints. Both suggest that financially healthy firms find it easier to start exporting. To put it differently, availability of financial resources shortens then time leading to first export. In a way, this should come as no surprise. Both the theoretical and empirical literature insist on the sunk costs implied by the expansion of activities abroad. Hence firms with stronger financial resources should be in a better position to cope with the extra costs - with no immediate compensation - associated with first exports. One surprise comes from the counter-intuitive sign of TFP, implying that more productive firms are less likely to enter into export markets. Although apparently at odds

\footnotetext{
${ }^{18}$ This choice is arbitrary. As of today, there is no particular reason to prefer the assumption of a Gamma-distributed frailty over the normal distributed one. This choice is mainly motivated by the fact that the Gamma distribution is particularly convenient to manipulate and has thus been the most popular. As displayed in Table 6, results under the alternative assumption are in all respect consistent with the Gamma assumption.
} 
Table 6: Estimating the hazard rate of entry into export markets

\begin{tabular}{|c|c|c|c|c|c|c|}
\hline & \multicolumn{2}{|c|}{ Pooled } & \multicolumn{2}{|c|}{ Normal $\mathrm{RE}^{\dagger}$} & \multicolumn{2}{|c|}{ Gamma $R^{\ddagger}$} \\
\hline & (1) & (2) & (3) & (4) & (5) & (6) \\
\hline \multirow[t]{2}{*}{ log Empl. } & 0.109 & 0.111 & 0.174 & 0.176 & 0.215 & 0.216 \\
\hline & {$[0.018]^{* * *}$} & {$[0.018]^{* * *}$} & {$[0.029]^{* * *}$} & {$[0.029]^{* * *}$} & {$[0.034]^{* * *}$} & {$[0.033]^{* * *}$} \\
\hline \multirow[t]{2}{*}{ log (Wage/Empl.) } & 0.829 & 0.832 & 0.972 & 0.971 & 1.010 & 1.009 \\
\hline & {$[0.051]^{* * *}$} & {$[0.051]^{* * *}$} & {$[0.073]^{* * *}$} & {$[0.071]^{* * *}$} & {$[0.071]^{* * *}$} & {$[0.071]^{* * *}$} \\
\hline \multirow[t]{2}{*}{$\log \mathrm{TFP}$} & -0.463 & -0.469 & -0.465 & -0.476 & -0.431 & -0.439 \\
\hline & {$[0.076]^{* * *}$} & {$[0.076]^{* * *}$} & {$[0.091]^{* * *}$} & {$[0.089]^{* * *}$} & {$[0.096]^{* * *}$} & {$[0.094]^{* * *}$} \\
\hline \multirow[t]{2}{*}{ Subsid. } & -0.029 & -0.028 & -0.047 & -0.046 & -0.058 & -0.058 \\
\hline & {$[0.041]$} & {$[0.041]$} & {$[0.046]$} & {$[0.046]$} & {$[0.049]$} & {$[0.049]$} \\
\hline \multirow[t]{2}{*}{ Score A } & 0.012 & & 0.016 & & 0.017 & \\
\hline & {$[0.006]^{* *}$} & & {$[0.007]^{* *}$} & & {$[0.008]^{* *}$} & \\
\hline \multirow[t]{2}{*}{ Liquidity Ratio } & & 0.012 & & 0.166 & & 0.175 \\
\hline & & {$[0.004]^{* * *}$} & & {$[0.039]^{* * *}$} & & {$[0.041]^{* * *}$} \\
\hline Observations & 35,794 & 35,794 & 35,794 & 35,794 & 35,794 & 35,794 \\
\hline Firms & & & 12,193 & 12,193 & 12,193 & 12,193 \\
\hline LR test ${ }^{\S}$ & & & $18.01^{* * *}$ & $17.65^{* * *}$ & $28.24^{* * *}$ & $27.96^{* * *}$ \\
\hline
\end{tabular}

Standard errors in brackets; sector and time dummies included

* significant at $10 \%$; ** significant at $5 \%$; *** significant at $1 \%$

$\dagger$ Random Effect model with Normal distributed frailty

$\ddagger$ Random Effect model with Gamma distributed frailty

$\S$ Likelihood Ratio test for unobserved frailty; $H_{0}$ : non significant unobserved frailty

with the theoretical literature (Melitz, 2003), this results is consistent with Bellone et al. (2008b), where a U-shaped productivity pattern is revealed for future French exporters. ${ }^{19}$ Lastly, both size and human capital, i.e. respectively employment and wage per employee, have the expected sign. These estimates imply that large firms intensive in human capital are more likely to go abroad.

Using model (5), Table 7 displays the estimated baseline hazard function for the representative firm. Note that in using a discrete time duration specification, hazard rates can be interpreted as probabilities of entry into export markets. First, we observe that the hazard rate function is monotonically decreasing in time, implying that the propensity of entry into export market is larger for young firms. This suggests that firms failing to expand abroad in their early years will find it increasingly difficult to start exporting. We observe that the probability of entry into export markets is $34 \%$ at the year of entry into the industry altogether, to reach $21 \%$ after year 13 . Second, Table 7 also displays the

\footnotetext{
${ }^{19}$ The paper shows that future exporters outperform their non exporting counterparts five years prior to entry into export market. But in their preparation to first export, firm productivity is found to temporarily decreases to then recover contemporaneously with entry. The interpretation is that the benefits from sales to foreign markets accrue at the time of entry, boosting the firm's level of productivity.
} 
Table 7: Estimated hazard rate of entry into export markets by deciles of explanatory variables

\begin{tabular}{|c|c|c|c|c|c|c|c|c|c|}
\hline \multirow{2}{*}{$\begin{array}{l}\text { Time } \\
\text { (in years) }\end{array}$} & \multirow{2}{*}{$\begin{array}{c}\text { Baseline } \\
\text { Hazard }\end{array}$} & \multicolumn{2}{|c|}{ Size } & \multicolumn{2}{|c|}{ Human Capital } & \multicolumn{2}{|c|}{ TFP } & \multicolumn{2}{|c|}{ Financial constraints } \\
\hline & & $1^{\text {st }}$ decile & $9^{t h}$ decile & $1^{\text {st }}$ decile & $9^{t h}$ decile & $1^{\text {st }}$ decile & $9^{t h}$ decile & $1^{s t}$ decile & $9^{t h}$ decile \\
\hline 1 & 0.343 & 0.308 & 0.395 & 0.089 & 0.604 & 0.370 & 0.318 & 0.331 & 0.354 \\
\hline 2 & 0.301 & 0.270 & 0.349 & 0.077 & 0.547 & 0.326 & 0.279 & 0.291 & 0.312 \\
\hline 3 & 0.279 & 0.250 & 0.324 & 0.070 & 0.515 & 0.302 & 0.258 & 0.269 & 0.289 \\
\hline 4 & 0.264 & 0.236 & 0.307 & 0.066 & 0.492 & 0.286 & 0.244 & 0.255 & 0.274 \\
\hline 5 & 0.253 & 0.226 & 0.295 & 0.063 & 0.475 & 0.274 & 0.234 & 0.244 & 0.262 \\
\hline 6 & 0.244 & 0.218 & 0.285 & 0.060 & 0.461 & 0.265 & 0.225 & 0.235 & 0.253 \\
\hline 7 & 0.237 & 0.211 & 0.277 & 0.058 & 0.449 & 0.257 & 0.219 & 0.228 & 0.245 \\
\hline 8 & 0.230 & 0.205 & 0.270 & 0.057 & 0.440 & 0.250 & 0.213 & 0.222 & 0.239 \\
\hline 9 & 0.225 & 0.201 & 0.263 & 0.055 & 0.431 & 0.245 & 0.208 & 0.217 & 0.234 \\
\hline 10 & 0.220 & 0.196 & 0.258 & 0.054 & 0.423 & 0.240 & 0.203 & 0.212 & 0.229 \\
\hline 11 & 0.216 & 0.193 & 0.253 & 0.053 & 0.417 & 0.235 & 0.200 & 0.208 & 0.224 \\
\hline 12 & 0.213 & 0.189 & 0.249 & 0.052 & 0.410 & 0.231 & 0.196 & 0.205 & 0.221 \\
\hline 13 & 0.209 & 0.186 & 0.245 & 0.051 & 0.405 & 0.227 & 0.193 & 0.202 & 0.217 \\
\hline
\end{tabular}

The table uses estimates from model (5) of table 6 
hazard function for firms located in the $1^{\text {st }}$ and $9^{\text {th }}$ decile of each significant explanatory variables, holding all other firm characteristics constant. For simplicity, we choose to comment year 5 exclusively. We observe the followings: firms located at the $9^{\text {th }}$ decile of Size (log of employees) are 30\% more likely to enter into export markets; firms located at the $9^{\text {th }}$ decile of Human Capital (Wage per employee) are 7 times more likely to enter into export markets than firms in the first decile; firms located at the $9^{\text {th }}$ decile of financial constraints (Score A) are 7\% more likely to enter into export markets.

The prominent role of human capital is suggestive that the variable serves as a proxy for a series of unobserved characteristics, such as informal personal ties, reputation, and the like. These unobserved characteristics are likely to become crucial when establishing activities in foreign countries. Turning to the effect of financial constraints, its limited magnitude $(7 \%)$ leads us to conclude that if their effect is statistically significant, its economic relevance is somewhat limited as compared with other variables. To recapitulate, we find that financial constraints are a significant determinant of firm export decision, but that as firm size, the impact of financial constraints upon the probability of exporting is far less important than the firm's endowment in human capital and skills. Next Section extends the analysis to investigate the role of financial constraints on firm-level export intensity.

\subsection{Accounting for initial export intensity}

Here, we tackle the issue of the relationship between financial constraints and export volume at the year of entry. Because positive exports implies that non-exporters be excluded from the sample of analysis, one must first correct for sample selection bias and depict in the qualitative equation the probability of being an exporter. In other words, explaining firm commitment to export markets necessarily calls for a broader investigation explaining why firms choose to expand their activities abroad in the first place. First, firms must decide whether to export and, conditional on this decision, they set the volume of their production to sell abroad. We model these two decisions by means of a Heckman model as follows

$$
y_{i t}=\mathbf{X}_{i, t-s} \beta+\sigma^{\prime} \lambda\left(\mathbf{X}_{i, t-s}^{\prime} \hat{\beta}^{\prime}\right)+\nu_{i}
$$

where $i$ stands for firm $i, t$ stands for year $t, y$ is export intensity, $\mathbf{X}$ is the vector of explanatory variables as previously defined, $\beta$ is the vector of parameter of interest and $\nu$ is an error term. ${ }^{20}$

\footnotetext{
${ }^{20}$ The Heckman specification augments the model by adding the inverse Mill's ratio $\lambda\left(\mathbf{X}_{i, t-s}^{\prime} \hat{\beta}^{\prime}\right)$, where $\hat{\beta}^{\prime}$ is obtained from the first step probit regression of export decision on $\mathbf{X}^{\prime}$, a vector of variables describing the determinants of export entry, which may or may not be equal to $\mathbf{X}$. In the present case, we set $\mathbf{X} \equiv \mathbf{X}^{\prime}$. Parameter $\sigma^{\prime}$ is then used to estimate $\rho$, a measure of selection bias correction.
} 
Table 8: Entry and export intensity: Heckman Two-Step model

$$
s=1
$$

\begin{tabular}{|c|c|c|c|c|c|c|c|c|}
\hline & & \\
\hline & $\begin{array}{l}\text { Export } \\
\text { decision }\end{array}$ & $\begin{array}{l}\text { Export } \\
\text { intensity }\end{array}$ & $\begin{array}{l}\text { Export } \\
\text { decision }\end{array}$ & $\begin{array}{l}\text { Export } \\
\text { intensity }\end{array}$ & $\begin{array}{l}\text { Export } \\
\text { decision }\end{array}$ & $\begin{array}{l}\text { Export } \\
\text { intensity }\end{array}$ & $\begin{array}{l}\text { Export } \\
\text { decision }\end{array}$ & $\begin{array}{l}\text { Export } \\
\text { intensity }\end{array}$ \\
\hline & $(1)$ & $(2)$ & $(3)$ & $(4)$ & $(5)$ & $(6)$ & $(7)$ & $(8)$ \\
\hline \multirow[t]{2}{*}{$\log \mathrm{Empl}_{t-s}$} & 0.047 & -0.032 & 0.052 & -0.038 & 0.067 & -0.007 & 0.072 & -0.02 \\
\hline & {$[0.031]$} & {$[0.069]$} & {$[0.031]^{*}$} & {$[0.070]$} & {$[0.052]$} & {$[0.112]$} & {$[0.052]$} & {$[0.113]$} \\
\hline \multirow[t]{2}{*}{$\log \mathrm{TFP}_{t-s}$} & -0.569 & -0.117 & -0.531 & -0.214 & -0.567 & -0.946 & -0.477 & -0.936 \\
\hline & {$[0.124]^{* * *}$} & {$[0.373]$} & {$[0.123]^{* * *}$} & {$[0.355]$} & {$[0.232]^{* *}$} & {$[0.537]^{*}$} & {$[0.232]^{* *}$} & {$[0.505]^{*}$} \\
\hline \multirow[t]{2}{*}{$\log (\text { Wage/Empl })_{t-s}$} & 0.511 & 0.333 & 0.514 & 0.361 & 0.134 & 0.555 & 0.130 & 0.551 \\
\hline & {$[0.085]^{* * *}$} & {$[0.297]$} & {$[0.085]^{* * *}$} & {$[0.297]$} & {$[0.154]$} & {$[0.303]^{*}$} & {$[0.154]$} & {$[0.303]^{*}$} \\
\hline \multirow[t]{2}{*}{ Subsid. $_{t-s}$} & 0.311 & 0.030 & 0.312 & 0.054 & 0.106 & 0.135 & 0.119 & 0.123 \\
\hline & {$[0.060]^{* * *}$} & {$[0.198]$} & {$[0.060]^{* * *}$} & {$[0.198]$} & {$[0.091]$} & {$[0.204]$} & {$[0.091]$} & {$[0.207]$} \\
\hline \multirow[t]{2}{*}{ Score $\mathrm{A}_{t-s}$} & 0.028 & -0.059 & & & 0.044 & -0.035 & & \\
\hline & {$[0.010]^{* * *}$} & {$[0.025]^{* *}$} & & & {$[0.017]^{* *}$} & {$[0.041]$} & & \\
\hline \multirow[t]{2}{*}{ Liquidity ratio $_{t-s}$} & & & 0.102 & -0.308 & & & 0.079 & -0.301 \\
\hline & & & {$[0.054]^{*}$} & {$[0.124]^{* *}$} & & & {$[0.099]$} & {$[0.196]$} \\
\hline Observations & \multicolumn{2}{|c|}{5727} & \multicolumn{2}{|c|}{5727} & \multicolumn{2}{|c|}{2169} & \multicolumn{2}{|c|}{2169} \\
\hline Wald $\chi^{2}$ & \multicolumn{2}{|c|}{$883.60^{* * *}$} & \multicolumn{2}{|c|}{$881.33^{* * *}$} & \multicolumn{2}{|c|}{$586.05^{* * *}$} & \multicolumn{2}{|c|}{$581.03^{* * *}$} \\
\hline$\rho$ & \multicolumn{2}{|c|}{-0.169} & \multicolumn{2}{|c|}{-0.111} & \multicolumn{2}{|c|}{-0.046} & \multicolumn{2}{|c|}{-0.053} \\
\hline
\end{tabular}

Standard errors in brackets

* significant at $10 \%$; ** significant at $5 \%$; *** significant at $1 \%$

Models include a vector of sector and time dummies 
Table 8 reports the results for both the selection equation explaining the decision of entry into export markets and the quantitative equation explaining export intensity at both time $t-1$ and time $t-3$. Again, we use both Score $\mathrm{A}$ and liquidity as proxies for financial constraints. Altogether, the qualitative equation shows consistency with the previous results concerning wage per employee and financial constraints, whereas the role of size vanishes. Looking at the quantitative equation at time $t-1$, the striking result is the switch in sign regarding financial constraints. Financially healthy firms are more likely to enter into export markets, but conditional on the decision to export entry, firms which commit more to international trade appear to be financially more constrained. We interpret these results as the fact that export intensity is also an indirect measure of sunk entry costs into export markets. The rationale for this is that export intensity increases with the number of foreign markets served by the firms. If some sunk costs may be shared across markets (e.g. to build a department dedicated to international trade), a substantial share of these costs are likely to be replicated for each country of destinations (e.g. the study the conformity of the manufactured product with regulatory environment). Hence if sunk entry costs increase with export intensity, the relationship between export intensity and financial constrained should indeed be negative.

The above remarks should call for caution. Our interpretation suggest that financial constraints suffer from a strong endogeneity problem yielding this negative association with export intensity. Importantly, the endogeneity problem is essentially caused by the simultaneous relationship between sunk costs of entry into export markets and financial health. Hence in order to control for that, we lag all explanatory variables three years. ${ }^{21}$ We find that three (five) years before entry, financially healthy firms find it easier to enter into export markets, but financial constraints are not associated with the choice of export intensity.

To recapitulate, financial health is an important determinant of the decision to enter into export markets made by firms. But firm commitment to foreign markets is chosen irrespective of financial health. The choices about the volume of export and the number of markets served are not driven by the availability of external financial resources. However, once the decision to export is validated, the appearance of the negative association between financial constraints and export intensity is suggestive that firms have to cope with extra expenditures to finance sunk entry costs into export markets. This decline in financial health may create transitory difficulties for future exporters, which may become more fragile, at least in the short run.

\footnotetext{
${ }^{21}$ We also experimented for a five-year lag but since the results are strictly equivalent to those using a three-year lag, we report the results for a three-year lag exclusively.
} 


\section{Conclusion}

In the last 10 years or so, a large empirical literature has emerged that studies the peculiar characteristics of exporting firms. Two broad stylized facts emerge: exporters perform substantially better than their non exporting competitors; there are wide cross-country differences in firm export behavior. This paper adds to this stream of the literature by looking at financial factors as a key determinant of firm decisions. More specifically, we investigate whether limited access to external financial resources may prevent firms from expanding their activities abroad, and whether internationalization has any positive effect on financial health.

We find strong evidence that less credit constrained firms self-select into export markets or, from a complementary point of view, that external funds are an important determinant of firm export status. In fact, export starters display better financial health than their non exporting competitors even before starting to operate abroad. On the contrary, the hypothesis that internationalization leads to better access to financial markets finds very limited support. In truth, firms heavily engaged in export activities appear to enjoy better financial health in the year after entry into foreign markets, but this phenomenon is shortlived and not particularly robust. Consistently with our previous findings, we observe that access to external financial resources is an important but not crucial determinant of the probability to start exporting. We find no evidence of a positive relationship between financial health and commitment to international trade. Conversely, higher export intensity is associated with lower financial health. This result is only apparently paradoxical since it corroborates the idea that the relevance of financial constraints is due to the presence of sunk entry costs. Since higher export intensity can be regarded as a proxy for the number of foreign markets served by a firm (Mayer and Ottaviano, 2007), exporting a higher share of production entails facing higher sunk entry costs (assuming that at least part of them are destination-specific), which drives down financial health.

All in all, we conclude that our empirical analysis supports recent models of international trade based on firm heterogeneity and sunk entry costs. In this context public intervention can be called upon to help efficient but constrained firms expand their activities abroad. More work needs to be done to investigate whether financial factors affect differently various types of firms, for instance resulting disproportionately more binding for small and young enterprises. Yet, the results presented in the paper already point to some policy conclusions. Indeed, the relevance of financial constraints in determining firm export behavior suggests that actions aimed either at reducing financial market imperfections or at lowering the sunk entry costs into foreign markets will be more successful in triggering export penetration than interventions providing guidance and support to existing exporters. 


\section{Acknowledgments}

The authors blame each other for any remaining mistake. They nevertheless agree on the need to thank Sylvain Barde, Jean-Luc Gaffard, Sarah Guillou, Mauro Napoletano and Evens Salies for insightful conversations. Seminar participants at GREDEG, University of Trento, the 2nd ACE International Conference in Hong Kong, the ISGEP Workshop in Nottingham, the 12th International Schumpeter Society Conference in Rio de Janeiro, and the 10th ETSG Conference in Warsaw provided us with valuable comments.

\section{References}

Almeida, H., Campello, M. and Weisbach, M. S. (2004), 'The cash flow sensitivity of cash', Journal of Finance 59(4), 1777-1804.

Aw, B. Y., Chung, S. and Roberts, M. (2000), 'Productivity and turnover in the export market: micro-level evidence from the Republic of Korea and Taiwan (China)', World Bank Economic Review 14(1), 65-90.

Baldwin, R. (1988), 'Hyteresis in import prices: The beachhead effect', American Economic Review 78(4), 773-85.

Becchetti, L. and Trovato, G. (2002), 'The determinants of growth of small and medium sized firms. The role of the availability of external finance', Small Business Economics 19(4), 291-306.

Bellone, F., Musso, P., Nesta, L. and Quéré, M. (2008a), 'Market selection along the firm life cycle', Industrial and Corporate Change 17(4), 753-77.

Bellone, F., Musso, P., Nesta, L. and Quéré, M. (2008b), 'The u-shaped productivity dynamics of French exporters', Review of World Economics 144(4), forthcoming.

Bernard, A. and Wagner, J. (2001), 'Export, entry, and exit by German firms', Review of World Economics 137, 105-23.

Bernard, A. B. and Jensen, J. B. (1995), 'Exporters, jobs, and wages in u.s. manufacturing: 1976-1987', Brookings Papers on Economic Activity 0(0), 67-112.

Bernard, A. B. and Jensen, J. B. (1999), 'Exceptional exporter performance: Cause, effect, or both?', Journal of International Economics 47(1), 1-25.

Bernard, A. B. and Jensen, J. B. (2004), 'Why some firms export', Review of Economics and Statistics 86(2), 561-69.

Bernard, A. B. and Wagner, J. (1997), 'Exports and success in german manufacturing', Weltwirtschaftliches Archiv 133(1), 134-57.

Bond, S. and Meghir, C. (1994), 'Dynamic investment models and the firm's financial policy', Review of Economic Studies 61(2), 197-222.

Bridges, S. and Guariglia, A. (2008), 'Financial constraints, global engagement, and firm 
survival in the United Kingdom: Evidence from micro data', Scottish Journal of Political Economy 55(4), 444-64.

Campa, J. (2004), 'Exchange rates and trade: How important is hysteresis in trade?', European Economic Review 48(3), 527-48.

Campa, J. M. and Shaver, J. M. (2002), Exporting and capital investment: On the strategic behavior of exporters, IESE Research Papers 469, IESE Business School.

Caves, D. W., Christensen, L. R. and Diewert, W. E. (1982), 'Multilateral comparisons of output, input, and productivity using superlative index numbers', Economic Journal 92(365), 73-86.

Chaney, T. (2005), Liquidity constrained exporters, mimeo, University of Chicago.

Chirinko, R. and Schaller, H. (1995), 'Why does liquidity matter in investment equations?', Journal of Money, Credit and Banking 27(2), 527-48.

Cleary, S. (1999), 'The relationship between firm investment and financial status', Journal of Finance 54(2), 673-92.

Cleary, S. (2006), 'International corporate investment and the relationships between financial constraint measures', Journal of Banking E Finance 30(5), 1559-80.

Das, S., Roberts, M. J. and Tybout, J. R. (2001), Market entry costs, producer heterogeneity, and export dynamics, Working Paper 8629, NBER.

Delgado, M., Farinas, J. and Ruano, S. (2002), 'Firm productivity and export markets: A non-parametric approach', Journal of International Economics 57(2), 397-422.

Devereux, M. and Schiantarelli, F. (1990), Investment, financial factors and cash flow: Evidence from U.K. panel data, in G. Hubbard, ed., 'Information, Capital Markets and Investment', University of Chicago Press, pp. 279-306.

Espanol, P. (2003), 'Why exporters can be financially constrained in a recently liberalised economy? A puzzle based on Argentinean firms during the 1990's'.

Fazzari, S., Hubbard, G. and Petersen, B. (1988), 'Financing constraints and corporate investment', Brookings Papers on Economic Activity 1, 141-95.

Ganesh-Kumar, A., Sen, K. and Vaidya, R. (2001), 'Outward orientation, investment and finance constraints: A study of indian firms', Journal of Development Studies 37(4), 133-149.

Gilchrist, S. and Himmelberg, C. (1995), 'Evidence on the role of cash flow for investment', Journal of Monetary Economics 36(3), 541-572.

Good, D. H., Nadiri, M. I. and Sickles, R. (1997), Index number and factor demand approaches to the estimation of productivity, in H. Pesaran and P. Schmidt, eds, 'Handbook of Applied Econometrics: Microeconometrics', Blackwell, Oxford, pp. 14-80.

Greenaway, D., Guariglia, A. and Kneller, R. (2005), Do financial factors affect exporting decisions?, GEP Research Paper 05/28, Leverhulme Center. 
Greenaway, D., Guariglia, A. and Kneller, R. (2007), 'Financial factors and exporting decisions', Journal of International Economics 73(2), 377-395.

Hoshi, T., Kashyap, A. and Scharfstein, D. (1991), 'Corporate structure, liquidity, and investment: Evidence from Japanese industrial groups', The Quarterly Journal of Economics 106(1), 33-60.

Hubbard, G. (1998), 'Capital-market imperfections and investment', Journal of Economic Literature 36(1), 193-225.

ISGEP (2008), 'Exports and productivity - Comparable evidence for 14 countries', Review of World Economics 144(4), forthcoming. The International Study Group on Exports and Productivity.

Jenkins, S. (1995), 'Easy ways to estimate discrete time duration models', Oxford Bulletin of Economics and Statistics 57, 129-138.

Kadapakkam, P.-R., Kumar, P. and Riddick, L. (1998), 'The impact of cash flows and firm size on investment: The international evidence', Journal of Banking \& Finance 22(3), 293-320.

Kaplan, S. and Zingales, L. (1997), 'Do investment-cash flow sensitivities provide useful measures of financing constraints?', The Quarterly Journal of Economics 112(1), 169215.

Lamont, O., Polk, C. and Saa-Requejo, J. (2001), 'Financial constraints and stock returns', Review of Financial Studies 14(2), 529-54.

Manova, K. (2006), Credit constraints, heterogeneous firms and international trade, mimeo, available at SSRN: http://ssrn.com/paper $=952552$.

Mayer, T. and Ottaviano, G. (2007), The happy few: the internationalisation of European firms, Blueprint 3, Bruegel.

Melitz, M. J. (2003), 'The impact of trade on intra-industry reallocations and aggregate industry productivity', Econometrica 71(6), 1695-1725.

Modigliani, F. and Miller, M. (1958), 'The cost of capital, corporation finance and the theory of investment', The American Economic Review 48(3), 261-97.

Moini, A. (2007), 'Export behavior of small firms: The impact of managenial attitudes', The International Executive 33(2), 14-20.

Musso, P. and Schiavo, S. (2008), 'The impact of financial constraints on firm survival and growth', Journal of Evolutionary Economics 18(2), 135-49.

Prentice, R. and Gloeckler, L. (1978), 'Regression analysis of grouped survival data with application to breast cancer data', Biometrics 34, 57-67.

Roberts, M. J. and Tybout, J. R. (1997), 'The decision to export in Colombia: an empirical model of entry with sunk costs', American Economic Review 87(4), 545-64.

Tornell, A. and Westermann, F. (2003), Credit market imperfections in middle income 
countries, Working Papers 9737, NBER.

Tybout, J. R. (2001), Plant- and firm-level evidence on "new" trade theories, Working Paper 8418, NBER.

Whited, T. and Wu, G. (2006), 'Financial constraints risk', Review of Financial Studies 19(2), 531-59. 
Elenco dei papers del Dipartimento di Economia

2000.1 A two-sector model of the effects of wage compression on unemployment and industry distribution of employment, by Luigi Bonatti

2000.2 From Kuwait to Kosovo: What have we learned? Reflections on globalization and peace, by Roberto Tamborini

2000.3 Metodo e valutazione in economia. Dall'apriorismo a Friedman, by Matteo Motterlini

2000.4 Under tertiarisation and unemployment. by Maurizio Pugno

2001.1 Growth and Monetary Rules in a Model with Competitive Labor Markets, by Luigi Bonatti.

2001.2 Profit Versus Non-Profit Firms in the Service Sector: an Analysis of the Employment and Welfare Implications, by Luigi Bonatti, Carlo Borzaga and Luigi Mittone.

2001.3 Statistical Economic Approach to Mixed Stock-Flows Dynamic Models in Macroeconomics, by Bernardo Maggi and Giuseppe Espa.

2001.4 The monetary transmission mechanism in Italy: The credit channel and a missing ring, by Riccardo Fiorentini and Roberto Tamborini.

2001.5 Vat evasion: an experimental approach, by Luigi Mittone

2001.6 Decomposability and Modularity of Economic Interactions, by Luigi Marengo, Corrado Pasquali and Marco Valente.

2001.7 Unbalanced Growth and Women's Homework, by Maurizio Pugno

2002.1 The Underground Economy and the Underdevelopment Trap, by Maria Rosaria Carillo and Maurizio Pugno.

2002.2 Interregional Income Redistribution and Convergence in a Model with Perfect Capital Mobility and Unionized Labor Markets, by Luigi Bonatti.

2002.3 Firms' bankruptcy and turnover in a macroeconomy, by Marco Bee, Giuseppe Espa and Roberto Tamborini.

2002.4 One "monetary giant" with many "fiscal dwarfs": the efficiency of macroeconomic stabilization policies in the European Monetary Union, by Roberto Tamborini.

2002.5 The Boom that never was? Latin American Loans in London 18221825 , by Giorgio Fodor. 
2002.6 L'economia senza banditore di Axel Leijonhufoud: le 'forze oscure del tempo e dell'ignoranza' e la complessità del coordinamento, by Elisabetta De Antoni.

2002.7 Why is Trade between the European Union and the Transition Economies Vertical?, by Hubert Gabrisch and Maria Luigia Segnana.

2003.1 The service paradox and endogenous economic gorwth, by Maurizio Pugno.

2003.2 Mappe di probabilità di sito archeologico: un passo avanti, di Giuseppe Espa, Roberto Benedetti, Anna De Meo e Salvatore Espa.

(Probability maps of archaeological site location: one step beyond, by Giuseppe Espa, Roberto Benedetti, Anna De Meo and Salvatore Espa).

2003.3 The Long Swings in Economic Understianding, by Axel Leijonhufvud.

2003.4 Dinamica strutturale e occupazione nei servizi, di Giulia Felice.

2003.5 The Desirable Organizational Structure for Evolutionary Firms in Static Landscapes, by Nicolás Garrido.

2003.6 The Financial Markets and Wealth Effects on Consumption An Experimental Analysis, by Matteo Ploner.

2003.7 Essays on Computable Economics, Methodology and the Philosophy of Science, by Kumaraswamy Velupillai.

2003.8 Economics and the Complexity Vision: Chimerical Partners or Elysian Adventurers?, by Kumaraswamy Velupillai.

2003.9 Contratto d'area cooperativo contro il rischio sistemico di produzione in agricoltura, di Luciano Pilati e Vasco Boatto.

2003.10 Il contratto della docenza universitaria. Un problema multi-tasking, di Roberto Tamborini.

2004.1 Razionalità e motivazioni affettive: nuove idee dalla neurobiologia e psichiatria per la teoria economica? di Maurizio Pugno.

(Rationality and affective motivations: new ideas from neurobiology and psychiatry for economic theory? by Maurizio Pugno.

2004.2 The economic consequences of Mr. G. W. Bush's foreign policy. Can th US afford it? by Roberto Tamborini

2004.3 Fighting Poverty as a Worldwide Goal by Rubens Ricupero

2004.4 Commodity Prices and Debt Sustainability by Christopher L. Gilbert and Alexandra Tabova 
2004.5 A Primer on the Tools and Concepts of Computable Economics by K. Vela Velupillai

2004.6 The Unreasonable Ineffectiveness of Mathematics in Economics by Vela K. Velupillai

2004.7 Hicksian Visions and Vignettes on (Non-Linear) Trade Cycle Theories by Vela K. Velupillai

2004.8 Trade, inequality and pro-poor growth: Two perspectives, one message? By Gabriella Berloffa and Maria Luigia Segnana

2004.9 Worker involvement in entrepreneurial nonprofit organizations. Toward a new assessment of workers? Perceived satisfaction and fairness by Carlo Borzaga and Ermanno Tortia.

2004.10 A Social Contract Account for CSR as Extended Model of Corporate Governance (Part I): Rational Bargaining and Justification by Lorenzo Sacconi

2004.11 A Social Contract Account for CSR as Extended Model of Corporate Governance (Part II): Compliance, Reputation and Reciprocity by Lorenzo Sacconi

2004.12 A Fuzzy Logic and Default Reasoning Model of Social Norm and Equilibrium Selection in Games under Unforeseen Contingencies by Lorenzo Sacconi and Stefano Moretti

2004.13 The Constitution of the Not-For-Profit Organisation: Reciprocal Conformity to Morality by Gianluca Grimalda and Lorenzo Sacconi

2005.1 The happiness paradox: a formal explanation from psycho-economics by Maurizio Pugno

2005.2 Euro Bonds: in Search of Financial Spillovers by Stefano Schiavo

2005.3 On Maximum Likelihood Estimation of Operational Loss Distributions by Marco Bee

2005.4 An enclave-led model growth: the structural problem of informality persistence in Latin America by Mario Cimoli, Annalisa Primi and Maurizio Pugno

2005.5 A tree-based approach to forming strata in multipurpose business surveys, Roberto Benedetti, Giuseppe Espa and Giovanni Lafratta.

2005.6 Price Discovery in the Aluminium Market by Isabel FiguerolaFerretti and Christopher L. Gilbert.

2005.7 How is Futures Trading Affected by the Move to a Computerized Trading System? Lessons from the LIFFE FTSE 100 Contract by Christopher L. Gilbert and Herbert A. Rijken. 
2005.8 Can We Link Concessional Debt Service to Commodity Prices? By Christopher L. Gilbert and Alexandra Tabova

2005.9 On the feasibility and desirability of GDP-indexed concessional lending by Alexandra Tabova.

2005.10 Un modello finanziario di breve periodo per il settore statale italiano: l'analisi relativa al contesto pre-unione monetaria by Bernardo Maggi e Giuseppe Espa.

2005.11 Why does money matter? A structural analysis of monetary policy, credit and aggregate supply effects in Italy, Giuliana Passamani and Roberto Tamborini.

2005.12 Conformity and Reciprocity in the "Exclusion Game": an Experimental Investigation by Lorenzo Sacconi and Marco Faillo.

2005.13 The Foundations of Computable General Equilibrium Theory, by K. Vela Velupillai.

2005.14 The Impossibility of an Effective Theory of Policy in a Complex Economy, by K. Vela Velupillai.

2005.15 Morishima's Nonlinear Model of the Cycle: Simplifications and Generalizations, by K. Vela Velupillai.

2005.16 Using and Producing Ideas in Computable Endogenous Growth, by K. Vela Velupillai.

2005.17 From Planning to Mature: on the Determinants of Open Source Take Off by Stefano Comino, Fabio M. Manenti and Maria Laura Parisi.

2005.18 Capabilities, the self, and well-being: a research in psychoeconomics, by Maurizio Pugno.

2005.19 Fiscal and monetary policy, unfortunate events, and the SGP arithmetics. Evidence from a growth-gap model, by Edoardo Gaffeo, Giuliana Passamani and Roberto Tamborini

2005.20 Semiparametric Evidence on the Long-Run Effects of Inflation on Growth, by Andrea Vaona and Stefano Schiavo.

2006.1 On the role of public policies supporting Free/Open Source Software. An European perspective, by Stefano Comino, Fabio M. Manenti and Alessandro Rossi.

2006.2 Back to Wicksell? In search of the foundations of practical monetary policy, by Roberto Tamborini

2006.3 The uses of the past, by Axel Leijonhufvud 
2006.4 Worker Satisfaction and Perceived Fairness: Result of a Survey in Public, and Non-profit Organizations, by Ermanno Tortia

2006.5 Value Chain Analysis and Market Power in Commodity Processing with Application to the Cocoa and Coffee Sectors, by Christopher L. Gilbert

2006.6 Macroeconomic Fluctuations and the Firms' Rate of Growth Distribution: Evidence from UK and US Quoted Companies, by Emiliano Santoro

2006.7 Heterogeneity and Learning in Inflation Expectation Formation: An Empirical Assessment, by Damjan Pfajfar and Emiliano Santoro

2006.8 Good Law \& Economics needs suitable microeconomic models: the case against the application of standard agency models: the case against the application of standard agency models to the professions, by Lorenzo Sacconi

2006.9 Monetary policy through the "credit-cost channel". Italy and Germany, by Giuliana Passamani and Roberto Tamborini

2007.1 The Asymptotic Loss Distribution in a Fat-Tailed Factor Model of Portfolio Credit Risk, by Marco Bee

2007.2 Sraffa?s Mathematical Economics - A Constructive Interpretation, by Kumaraswamy Velupillai

2007.3 Variations on the Theme of Conning in Mathematical Economics, by Kumaraswamy Velupillai

2007.4 Norm Compliance: the Contribution of Behavioral Economics Models, by Marco Faillo and Lorenzo Sacconi

2007.5 A class of spatial econometric methods in the empirical analysis of clusters of firms in the space, by Giuseppe Arbia, Giuseppe Espa e Danny Quah.

2007.6 Rescuing the LM (and the money market) in a modern Macro course, by Roberto Tamborini.

2007.7 Family, Partnerships, and Network: Reflections on the Strategies of the Salvadori Firm of Trento, by Cinzia Lorandini.

2007.8 I Verleger serici trentino-tirolesi nei rapporti tra Nord e Sud: un approccio prosopografico, by Cinzia Lorandini.

2007.9 A Framework for Cut-off Sampling in Business Survey Design, by Marco Bee, Roberto Benedetti e Giuseppe Espa

2007.10 Spatial Models for Flood Risk Assessment, by Marco Bee, Roberto Benedetti e Giuseppe Espa 
2007.11 Inequality across cohorts of households:evidence from Italy, by Gabriella Berloffa and Paola Villa

2007.12 Cultural Relativism and Ideological Policy Makers in a Dynamic Model with Endogenous Preferences, by Luigi Bonatti

2007.13 Optimal Public Policy and Endogenous Preferences: an Application to an Economy with For-Profit and Non-Profit, by Luigi Bonatti

2007.14 Breaking the Stability Pact: Was it Predictable?, by Luigi Bonatti and Annalisa Cristini.

2007.15 Home Production, Labor Taxation and Trade Account, by Luigi Bonatti.

2007.16 The Interaction Between the Central Bank and a Monopoly Union Revisited: Does Greater Uncertainty about Monetary Policy Reduce Average Inflation?, by Luigi Bonatti.

2007.17 Complementary Research Strategies, First-Mover Advantage and the Inefficiency of Patents, by Luigi Bonatti.

2007.18 DualLicensing in Open Source Markets, by Stefano Comino and Fabio M. Manenti.

2007.19 Evolution of Preferences and Cross-Country Differences in Time Devoted to Market Work, by Luigi Bonatti.

2007.20 Aggregation of Regional Economic Time Series with Different Spatial Correlation Structures, by Giuseppe Arbia, Marco Bee and Giuseppe Espa.

2007.21 The Sustainable Enterprise. The multi-fiduciary perspective to the EU Sustainability Strategy, by Giuseppe Danese.

2007.22 Taming the Incomputable, Reconstructing the Nonconstructive and Deciding the Undecidable in Mathematical Economics, by K. Vela Velupillai.

2007.23 A Computable Economist's Perspective on Computational Complexity, by K. Vela Velupillai.

2007.24 Models for Non-Exclusive Multinomial Choice, with Application to Indonesian Rural Households, by Christopher L. Gilbert and Francesca Modena.

2007.25 Have we been Mugged? Market Power in the World Coffee Industry, by Christopher L. Gilbert. 
2007.26 A Stochastic Complexity Perspective of Induction in Economics and Inference in Dynamics, by K. Vela Velupillai.

2007.27 Local Credit ad Territorial Development: General Aspects and the Italian Experience, by Silvio Goglio.

2007.28 Importance Sampling for Sums of Lognormal Distributions, with Applications to Operational Risk, by Marco Bee.

2007.29 Re-reading Jevons's Principles of Science. Induction Redux, by K. Vela Velupillai.

2007.30 Taking stock: global imbalances. Where do we stand and where are we aiming to? by Andrea Fracasso.

2007.31 Rediscovering Fiscal Policy Through Minskyan Eyes, by Philip Arestis and Elisabetta De Antoni.

2008.1 A Monte Carlo EM Algorithm for the Estimation of a Logistic Autologistic Model with Missing Data, by Marco Bee and Giuseppe Espa.

2008.2 Adaptive microfoundations for emergent macroeconomics, Edoardo Gaffeo, Domenico Delli Gatti, Saul Desiderio, Mauro Gallegati.

2008.3 A look at the relationship between industrial dynamics and aggregate fluctuations, Domenico Delli Gatti, Edoardo Gaffeo, Mauro Gallegati.

2008.4 Demand Distribution Dynamics in Creative Industries: the Market for Books in Italy, Edoardo Gaffeo, Antonello E. Scorcu, Laura Vici.

2008.5 On the mean/variance relationship of the firm size distribution: evidence and some theory, Edoardo Gaffeo, Corrado di Guilmi, Mauro Gallegati, Alberto Russo.

2008.6 Uncomputability and Undecidability in Economic Theory, K. Vela Velupillai.

2008.7 The Mathematization of Macroeconomics: A Recursive Revolution, K. Vela Velupillai.

2008.8 Natural disturbances and natural hazards in mountain forests: a framework for the economic valuation, Sandra Notaro, Alessandro Paletto

2008.9 Does forest damage have an economic impact? A case study from the Italian Alps, Sandra Notaro, Alessandro Paletto, Roberta Raffaelli.

2008.10 Compliance by believing: an experimental exploration on social norms and impartial agreements, Marco Faillo, Stefania Ottone, Lorenzo Sacconi. 
2008.11 You Won the Battle. What about the War? A Model of Competition between Proprietary and Open Source Software, Riccardo Leoncini, Francesco Rentocchini, Giuseppe Vittucci Marzetti.

2008.12 Minsky's Upward Instability: the Not-Too-Keynesian Optimism of a Financial Cassandra, Elisabetta De Antoni.

2008.13 A theoretical analysis of the relationship between social capital and corporate social responsibility: concepts and definitions, Lorenzo Sacconi, Giacomo Degli Antoni.

2008.14 Conformity, Reciprocity and the Sense of Justice. How Social Contract-based Preferences and Beliefs Explain Norm Compliance: the Experimental Evidence, Lorenzo Sacconi, Marco Faillo.

2008.15 The macroeconomics of imperfect capital markets. Whither savinginvestment imbalances? Roberto Tamborini

2008.16 Financial Constraints and Firm Export Behavior, Flora Bellone, Patrick Musso, Lionel Nesta and Stefano Schiavo 
PUBBLICAZIONE REGISTRATA PRESSO IL TRIBUNALE DI TRENTO 